\title{
Extreme Weather and Flood Forecasting and Modelling for Eastern Tana Sub Basin, Upper Blue Nile Basin, Ethiopia
}

\author{
Ayenew Desalegn ${ }^{1 *}$, Solomon Demissie ${ }^{2}$ and Seifu Admassu ${ }^{2}$
}

${ }^{1}$ Department of Meteorology and Hydrology, Institute of Technology, Arba Minch University, Arba Minch, Ethiopia

${ }^{2}$ School of Civil and Water Resources Engineering, Bahir Dar Institute of Technology, Bahir Dar University, Bahir Dar, Ethiopia

\begin{abstract}
River flood is a natural disaster that occurs each year in the Fogera floodplain causing enormous damage to the human life and property. Overflow of Ribb and Gummara rivers and backwater effects from Lake Tana has affected and displaced thousands of people since 2006. Heavy rainfall for a number of days in the upper stream part of the catchment caused the river to spill and to inundate the floodplain. Three models were used for this research; the numerical weather prediction model (WRF), physical based semi distributed hydrological model SWAT and the LISFLOOD-FP 1D/2D flood inundation hydrodynamic model to forecast the extreme weather, flood and flood modeling. Daily rainfall, maximum and minimum temperature for the forecasted period ranges from 0 to $95.8 \mathrm{~mm}$, $18^{\circ} \mathrm{C}$ to $28^{\circ} \mathrm{C}$ and $9^{\circ} \mathrm{C}$ to $18^{\circ} \mathrm{C}$, respectively. The maximum forecasted flow at Ribb and Gummara Rivers have 141 $\mathrm{m}^{3} / \mathrm{s}$ and $185 \mathrm{~m}^{3} / \mathrm{s}$ respectively. The flood extent of the forecasted period is $32 \mathrm{~km}^{2}$; depth ranges $0.01 \mathrm{~m}$ to 3.5 $\mathrm{m}$; and velocity ranges from 0 to $2.375 \mathrm{~m} / \mathrm{s}$. This technique has shown to be an effective way of flood forecasting and modeling. Integrating Rainfall Runoff model with hydrodynamic model provides thus good alternative for flood forecasting and modeling.
\end{abstract}

Keywords: SWAT; LISFLOOD; WRF; Extreme weather; Forecasting and modeling

\section{Introduction}

Weather-related disasters are increasing in intensity and are expected to increase with climate change [1]. Approximately $70 \%$ of all disasters occurring in the world are related to hydro-meteorological event [2]. Death and destruction due to flooding continue to be all too common phenomena throughout the world; and affecting millions of people annually, which is about a third of all natural disasters throughout the world and are responsible for more than half of the fatalities [3].

Scientists agreed that changes in the earth's climate will hit developing countries like Ethiopia first and the hardest because their economic are strongly dependent on crude forms of natural resources and their economic structure is less flexible to adjust to such drastic changes [4]. In Ethiopia, floods are common and occurring throughout the country with varying time and magnitude. Flood disasters are caused by rivers overflow or burst their banks and inundate to downstream flood plain land; particularly large scale flooding (riverine flooding) in the country is common in the low land flat parts due to high intensity of rainfall from highland parts [5].

As recently as 2006, flooding occurred in almost all parts of the country and devastate the entire country of which Lake Tana remains one of these areas regularly inundated. In spite of the recurrent flood problem, the existing disaster management mechanism has primarily focused on strengthening rescue and relief arrangements during and after flood disasters. Little work has been done in scientific context on minimizing the incidence and extent of flood damage; but need to forecast the extreme weather as well as extreme weather related disasters.

Hence, it is essential to forecast and model the occurrence of extreme weather related disasters to secure human life and property. Therefore, the objective of this study is to forecast extreme weather and flood, and evaluate the applicability of integrating WRF-SWATLISFLOOD-FP models to forecast flooding in Fogera floodplain, Easter Tana sub basin.

\section{Materials and Methods}

\section{Study area}

The study has conducted in the upper Blue Nile part of Ethiopia in Amahara Region, South Gondar Zone. Geographically the area is located between $10^{\circ} 57^{\prime}$ and $12^{\circ} 47^{\prime} \mathrm{N}$ and $36^{\circ} 38^{\prime}$ and $38^{\circ} 14^{\prime} \mathrm{E}$ (Figure 1). It has an aerial extent of about $4174.33 \mathrm{~km}^{2}$ drained by Ribb and Gummara Rivers; which is nearly $600 \mathrm{~km}$ away from Addis Ababa. Different geographic futures like flood plain, high mountainous land with cold weather (Guna Mountain), Plateau, and rivers characterize it. The basins topography ranges from $1783 \mathrm{~m}$ near to Lake Tana up to $4089 \mathrm{~m}$ above mean see level on Guna Mountain. The climate is tropical highland monsoon where the seasonal rainfall distribution is controlled by the movement of the inter-tropical convergence zone and moist air from the Atlantic and Indian Ocean in the summer (JuneSeptember) [6]. The northward and southward movement of the InterTropical Convergence Zone (ITCZ) controls the seasonal distribution of rainfall. Moist air masses have driven from the Atlantic and Indian Oceans during summer (June-September). During the rest of the year the ITCZ shifts southwards and dry conditions persists in the region between October and May.

\section{The data set}

Time series daily rainfall and temperature data for the selected

*Corresponding author: Ayenew Desalegn, Department of Meteorology and Hydrology, Institute of Technology, Arba Minch University, Arba Minch, Ethiopia Tel: +251910721861; E-mail: aye.desalegn@gmail.com

Received August 13, 2016; Accepted August 31, 2016; Published September 07,2016

Citation: Desalegn A, Demissie S, Admassu S (2016) Extreme Weather and Flood Forecasting and Modelling for Eastern Tana Sub Basin, Upper Blue Nile Basin, Ethiopia. Hydrol Current Res 7: 257. doi: 10.4172/2157-7587.1000257

Copyright: (c) 2016 Desalegn A, et al. This is an open-access article distributed under the terms of the Creative Commons Attribution License, which permits unrestricted use, distribution, and reproduction in any medium, provided the original author and source are credited. 


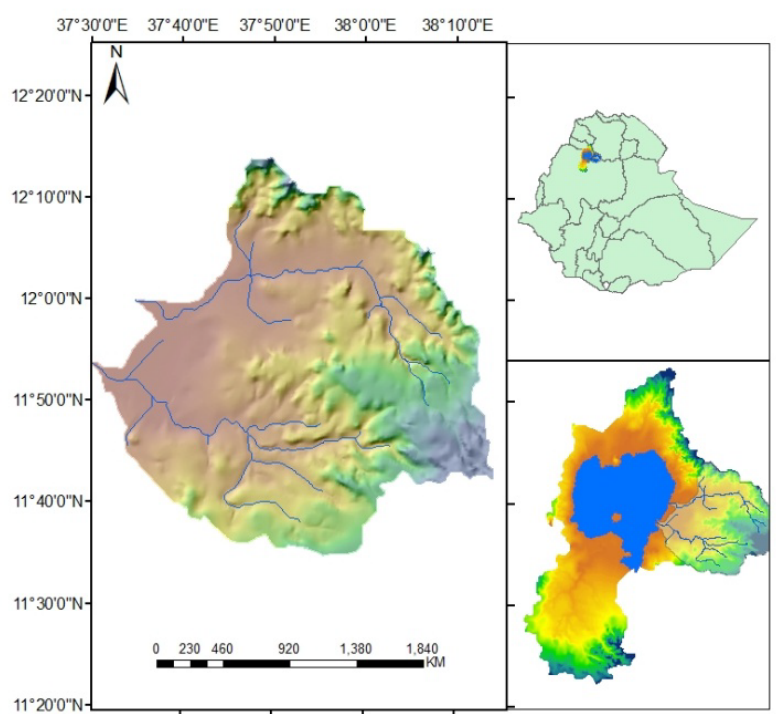

Figure 1: Study area.

stations from 1951-2014 were obtained from National Meteorological Agency of Ethiopia (NMA). The other variables evapotranspiration, solar radiation, wind speed and relative humidity, have simulated from SWAT weather Generator. Similarly, daily stream flow data of Ribb and Gummara rivers for the years of 1973 to 20014 have obtained from Ethiopian ministry of water Irrigation and Energy.

Spatial resolution of $30 \times 30 \mathrm{~m}$ land use image has downloaded from landsat8 OPL sensor with 169 Path and 52 Row for 01/02/2014 and reclassified using supervised maximum likelihood land use classification method using GIS technique. In addition, soil data has extracted from Blue Nile Basin soil data (Soill90) obtained from Ministry of Water Irrigation and Energy of Ethiopia (MoWIE). River cross section data of Ribb and Gummara Rivers and Survey data for Fogera flood Plain have obtained from Tana Sub Basin Office (TaSBO) which has collected by MoWIE. The rivers width has also obtained by digitizing from ESRi high-resolution world imagery base map of resolution $1 \mathrm{~m}$ and better of resolutions $(15 \mathrm{~cm}$ and $60 \mathrm{~cm}$ ) on ArcGIS map window.

\section{Extreme weather forecasting}

Extreme weather has forecasted for the entire period of August 20, 2006-Sepetember 10, 2006 using a numerical weather prediction WRF model. To forecast the extreme weather nested three domains [Ethiopia $(45 \mathrm{~km})$, Northern part $(15 \mathrm{~km})$, and fogera $(5 \mathrm{~km})]$ resolution were selected by assuming that 1-degree $\sim 111 \mathrm{~km}$ around equator. The model handled three domains at the same nest level (no overlapping nests), and/or three nest levels (telescoping). The nesting ratio for the WRF-ARW is three and the grid spacing of a nest was $1 / 3$ of its parent.

The initial and lateral boundary, meteorological and terrestrial gridded data that used to run the WRF-ARW model has downloaded from Global Forecasting System (GFS) that has produced by the National Centers for Environmental Prediction (NCEP) and it has updated for every six hours. The Real-data has interpolated to run the NWP using WRF Pre-processing System (WPS). The WRF Model (ARW dynamical cores) was initialized numerical integration programs for real data processing. The output of the model WRF-ARW has processed on WRF-post processing and visualized using Grid Analysis and Display System (GRADS). The output of the WRF model, weather data, has processed for SWAT model input. From the output of the model few parameter has selected and used as SWAT model impute (Figure 2).

\section{Runoff forecasting}

A conceptual, physically based, continuous SWAT model has employed to simulate stream flow. The SWAT (Soil and Water Assessment Tool) model was developed by the USDA (U.S. Department of Agriculture), ARS (Agriculture Research Service) and represents a continuation of roughly 40 years of modeling efforts [7]. SWAT is a public domain watershed scale model developed to predict the effects of land management on water, sediment, nutrients, pesticides and agricultural chemicals in small to large complex basins [8]. It is a physically based, semi-distributed parameter model with a robust hydrologic and pollution element that has successfully employed in a number of watersheds. Widely known application of SWAT model is simulating hydrology of a watershed, water quality, sediment yield and plant growth in relation to watershed management practices.

However, it has also applied for flow forecasting. The soil and water assessment tool (SWAT) can forecast the flow of a watershed but it is performed lower than Artificial Neural Network (ANN) models [9]. Hydrological modeling of a SWAT has used in flash flood forecasting with the application of three days weather forecast from the NWP (Numerical Weather Prediction) and the data from the NWP can be used with the SWAT model and provides relatively sound results [10]. Predicting flood hazard areas and damage reduction by flood inundation and the sediments using SWAT and HEC-RAS $[11,12]$.

The major components of SWAT are climate, hydrology, erosion, land cover and plant growth, nutrients, pesticides and land management. The SWAT has used to simulate the hydrologic processes of the study watershed. Simulations of the hydrology of a watershed can separated into two major divisions. The first division is the land phase of the hydrologic cycle and the second division is the water or routing phase of the cycle [10].

For Land phase, the hydrologic cycle has based on the water balance equation:

$$
\mathrm{SW}_{\mathrm{t}}=\mathrm{SW}_{0}+\sum_{\mathrm{I}=0}^{\mathrm{t}}\left(\mathrm{R}_{\mathrm{t}}-\mathrm{Q}_{\text {surf }}-\mathrm{E}_{\mathrm{a}}-\mathrm{W}_{\text {seep }}-\mathrm{Q}_{\mathrm{gw}}\right.
$$

Where, $\mathrm{SW}_{\mathrm{t}}=$ final water content $(\mathrm{mm})$

$$
\mathrm{SW}_{0}=\text { initial water content in time } \mathrm{I}(\mathrm{mm})
$$

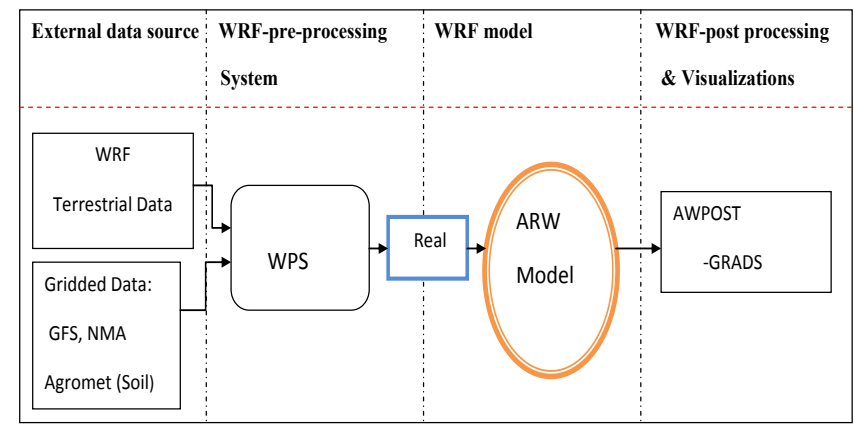

Figure 2: WRF model Approach. 
$\mathrm{t}=$ time (in days, months, or years)

$\mathrm{R}_{\mathrm{t}}=$ amount of rainfall in time $\mathrm{I}(\mathrm{mm})$

$\mathrm{Q}_{\text {surf }}=$ amount of surface runoff in time I (mm)

$\mathrm{E}_{\mathrm{a}}=$ amount of evapotranspiration in time $\mathrm{I}(\mathrm{mm})$

$\mathrm{W}_{\text {seep }}=$ amount of water entering the vadose zone from the soil profile in time I $(\mathrm{mm})$

$\mathrm{Q}_{\mathrm{gw}}=$ amount of return or base flow in time $\mathrm{I}(\mathrm{mm})$.

Surface runoff: Also known as overland flow, the part of the rainfall, infiltration excesses rainfall flowing along the slopes. SWAT uses the Soil Conservations Service (SCS) Curve Number (CN) method to calculate surface runoff. Surface runoff can express using the equation 2:

$$
\mathrm{Q}_{\text {surf }}=\frac{\left(\mathrm{R}_{\text {day }}-\mathrm{I}_{\mathrm{a}}\right)^{2}}{\mathrm{R}_{\text {day }}-\mathrm{I}_{\mathrm{a}}+\mathrm{S}} \text { and } \mathrm{I}_{\mathrm{a}}=0.2 \times \mathrm{S}
$$

Where, $S=$ soil storage or retention

$$
\mathrm{R}_{\text {day }}=\text { daily precipitation }
$$

$I_{a}=$ initial surface abstraction that includes surface storage, interception and infiltration to moist soil surface up to runoff generation, all in $\mathrm{mm}$ water.

Soil storage or retention volume has expressed in terms of curve number $\mathrm{CN}$ (equation 3)

$$
\mathrm{S}=25.4\left(\frac{1000}{\mathrm{CN}}-10\right)
$$

By substituting $I_{a}$ and $S$ in equation 2, surface runoff is expressed as:

$$
\mathrm{Q}_{\text {surf }}=\frac{\left(\mathrm{R}_{\text {day }}-0.2 \mathrm{~S}\right)^{2}}{\mathrm{R}_{\text {day }}+0.8 \mathrm{~S}}
$$

Surface runoff will occur when the amount of rainfall amount exceeds the initial abstraction and infiltration to the root zone of the soil. For a reason, $\mathrm{CN}$ is a function of land-use, soil and antecedent soil moisture content. These functional relationship and $\mathrm{CN}$ values can be obtained in the SWAT manual and user guide [13].

Before forecasting, the model has calibrated and validated using observed flow data. From the available data, 2 years (1994-1996) for warm-up, 9 years (1996-2004) for calibration and 5 years (20052009) for validation have used. Model calibration was performed using the Sequential Uncertainty Fitting version 2 (SUFI-2) interface of SWAT-CUP. SWAT-CUP is a separate calibration and uncertainty program developed by Abbaspour. It is a commonly used procedure for calibration and uncertainty analysis. Setegn et al. [14,15] compared different procedures and found SUFI-2 is better that gives good results even at smallest number of runs as compared to other procedures. The performance of model was evaluated using dimensionless NashSutcliffe Efficiency (NSE) (Nash and Sutcliffe) and coefficient of determination $\left(\mathrm{R}^{2}\right)$.

\section{Flood modeling and forecasting}

Among the most widely used hydraulic models LISFLOOD model has selected for this research. LISFLOOD is a distributed, raster- based; combination rainfall-runoff and hydrodynamic model embedded in a dynamic GIS environment [16-18], and has been developed for the simulation of hydrological processes and floods in European drainage basins. It is a flexible tool, which is capable of simulating hydrological processes on a wide range of spatial and temporal scales, maintaining high resolution even when simulating large catchment areas.

LISFLOOD-FP (Flood Plain) raster based inundation model. It shows a $2 \mathrm{D} / 3 \mathrm{D}$ simulation of the floodplain has inundated and runs at a time step of seconds. The inputs for this module are, a high resolution DEM including all the topographic detail of features inside the modeled area considered necessary to produce probable flood inundation prediction, the rivers hydrograph, a map of flood source areas, and the outputs of the Flood Simulation model [17].

The LISFLOOD-FP, one of the modules of LISFLOOD, includes a number of numerical schemes (solvers) which simulate the propagation of flood waves along channels and across floodplains using the shallow water equations. The choice of numerical scheme is depend on the characteristics of the system has to be modeled, requirements of time for execution and type of data available. The momentum and continuity equations for the $1 \mathrm{D}$ full shallow water equations have given below (equations 5,6 respectively):

$$
\frac{\partial \mathrm{Qx}}{\partial \mathrm{t}}+\frac{\partial}{\partial \mathrm{x}}\left(\frac{\mathrm{Q}_{\mathrm{x}}{ }^{2}}{\mathrm{~A}}\right)+\mathrm{gA} \frac{\partial(\mathrm{h}+\mathrm{z})}{\partial \mathrm{x}}+\frac{\mathrm{gQ}_{\mathrm{x}}{ }^{2} \mathrm{n}^{2}}{\mathrm{R}^{4 / 3} \mathrm{~A}}=0
$$

$$
\frac{\partial \mathrm{A}}{\partial \mathrm{x}}+\frac{\partial \mathrm{Qx}}{\partial \mathrm{x}}=0
$$

Where, $Q_{x}=$ volumetric flow rate in the $x$ Cartesian direction

$\mathrm{A}=$ cross sectional area of flow

$\mathrm{h}=$ water depth

$\mathrm{z}=$ bed elevation

g=gravity

$\mathrm{n}=$ Manning's coefficient of friction

$\mathrm{R}=$ hydraulic radius

$\mathrm{t}=$ time

$\mathrm{x}=$ distance in the $\mathrm{x}$ Cartesian direction.

Floodplain flow solvers: LISFLOOD Roe: The "Roe" solver includes all of the terms in the full shallow water equations was selected for this research [19]. The method has based on the Godunov approach and uses an approximate Riemann solver by Roe based on the TRENT model presented in Villanueva and Wright. The explicit descritisation is first order in space on a raster grid. It solves the full shallow water equations with a shock-capturing scheme. LISFLOOD-Roe uses a point wise friction based on the Manning's equation, while the domain boundary/internal boundary (wall) uses the ghost cell approach. The stability of this approach has approximated by the Courant-FriedrichsLevy (CFL) condition for shallow water models.

$$
\frac{\partial \mathrm{Q}}{\partial \mathrm{t}}+\frac{\partial}{\partial \mathrm{x}}\left(\frac{\mathrm{Q}^{2}}{\mathrm{~A}}\right)+\mathrm{gA} \frac{\partial\left(\mathrm{h}_{\mathrm{t}}+\mathrm{z}\right)}{\partial \mathrm{x}}+\frac{\mathrm{gQ}^{\mathrm{t}} \mathrm{n}^{2}}{\mathrm{R}^{4 / 3} \mathrm{~A}}=0
$$


Where, $\mathrm{Q}=$ discharge

$\mathrm{t}=$ time

$\mathrm{A}=$ cross section area

g=gravitational constant

$\mathrm{h}_{\mathrm{t}}=$ water free surface height

$\mathrm{z}=$ bed elevation

$\mathrm{n}=$ Manning's coefficient

$\mathrm{R}=$ Hydraulic Radius.

Channel flow solvers: The "diffusive" channel flow solver has selected for this research uses the 1D diffusive wave equations and it includes the water slope term, which is able to predict backwater effects. Using the 1D-channel solvers, once channel water depth reaches bank full ight, water has routed onto adjacent floodplain cells has distributed as per the chosen floodplain solver. There is no transfer of momentum between the channel and floodplain, only mass. The $1 \mathrm{D}$ diffusive solvers assume that the in-channel flow component can be represented using a diffusive $1 \mathrm{D}$ wave equation with the channel geometry simplified to a rectangle. The $1 \mathrm{D}$ diffusive channel flow solver assumes that the channel to be wide and shallow, so the wetted perimeter is approximated by the channel width such that the lateral friction is neglected.

\section{Results and Discussion}

\section{Extreme weather forecasting}

The extreme weather for the study area has forecasted using a numerical weather prediction model WRF-ARW from 20 August 2006-10 September 2006. The weather parameters have forecasted at a six-hour time step and converted to daily for SWAT model input. Air temperature, wind speed at two meter, solar radiation, relative humidity, precipitation, geopotential height, sea surface temperature and Surface temperature were among the outputs of the WRF model. Precipitation and temperature of the output parameters have selected for SWAT model input to forecast the flood. The result in Figure 3 shows that Eastern Tana Sub basin has subjected to intense and heavy rains during the selected period. The developments of intensive weather events that invade Eastern Tana sub basin during 20 August 2006-7 September 2006, have characterized by "exceptional and extremely heavy rainfall," which affected almost all part of the Eastern Tana Sub Basin.

The forecasted rainfall of the selected station has obtained from the WRF output gridded data. Unfortunately, the selected stations point has no the same coordinate with girded point. Hence, the forecasted rainfall for the station points has obtained from the neighboring gridded points using regression method. The cumulative of forecasted rainfall is similar with the cumulative of the observed. The forecasted daily rainfall for the forecasted period ranges from 0 to $95.8 \mathrm{~mm}$. A very intense and heavy rain has occurred during $25^{\text {th }}$ of the days almost all over the entire sub basin. Even though the WRF model captures rainfall climatology in the study area both in space and time basin, there is variations of the forecasted rainfall for selected stations. The maximum rainfall has recorded in the upper part of the sub basin climatological stations, which are D/Tabor, Lewaye, K/Dnigay and M/Eyesus for the entire period. The maximum daily rainfall has observed at K/Dnigay station about $95.8 \mathrm{~mm}$ followed by Lewaye and $\mathrm{D} /$ Tabor stations about $60 \mathrm{~mm}$ and $40 \mathrm{~mm}$ respectively. In the meanwhile, the minimum daily rainfall has recorded in the lower part of the study area stations, which were Yifag, Wanzaye (Figure 4).

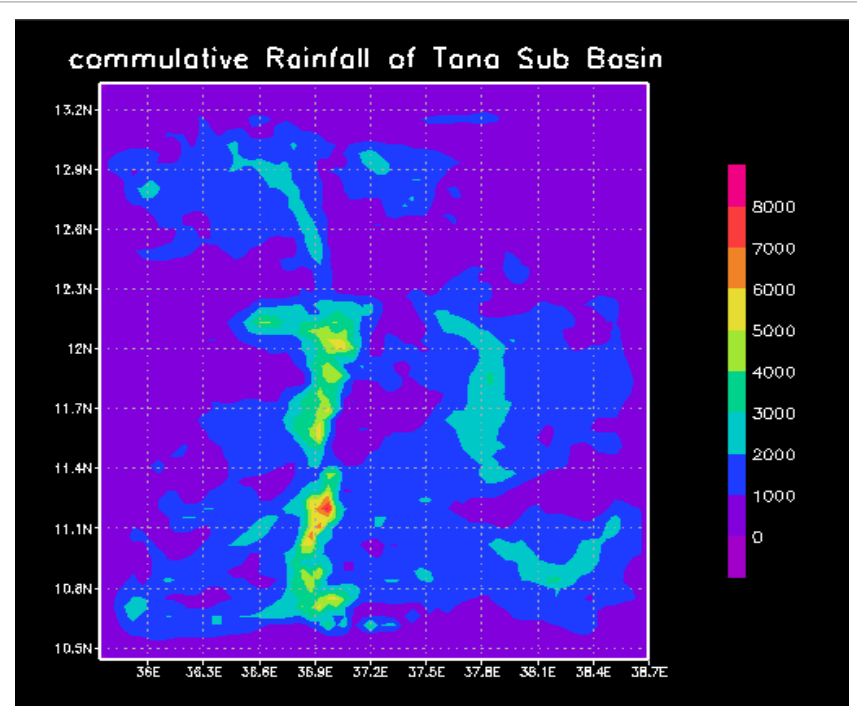

Figure 3: Forecasted rainfall.

Similarly, the forecasted temperature for the station points has obtained from the neighboring gridded points using regression method (Figure 5). As can be seen Figure 6, the spatial variation of average temperature over the Tana Sub basin.

The maximum forecasted air temperature for the selected period of the entire sub basin ranges from $18^{\circ} \mathrm{C}$ to $28^{\circ} \mathrm{C}$. Generally, the WRF model has well forecasted the maximum temperature compared with the observed data for the sub basin.

\section{Flow modelling and forecasting}

Hydrological model calibration and validation: The calibration and validation of the model was a key factor in reducing the uncertainty and increasing confidence in its predicative abilities, which makes the application an effective model. Information on the sensitivity analysis, calibration and validation of multivariable SWAT models was provided to assist watershed modelers in developing their models to achieve their watershed management goals [20]. SWAT simulation has executed for the 1994-2009 period to provide two-years for an initialization period. Calibration of SWAT has performed for 1994-2004, while 2005-2009 have used as the validation years.

The goodness of fit of the model is evaluated using coefficient of determination $\left(\mathrm{R}^{2}\right)$ and Nash-Sutcliffe Efficiency (NSE). It has found that the model has strong predictive capability as shown in Table 1. Statistical model efficiency criteria fulfilled the requirement of $\mathrm{R}^{2}>0.6$ and NSE $>0.5$ which is recommended by SWAT developer [21]. This showed the model parameters represent the processes occurring in the watershed to the best of their ability given available data and can used to predict watershed response for various outputs (Figures 7 and 8).

Flow forecasting: The forecasted weather data using NWP-WRF model has used as input for SWAT model. The simulated value has considered as forecasted flow. It has also found that the simulated flow rate using NWP-WRF data was lower than the observations for both watersheds for consecutive five days from 27 August 2006-1 September 2006. This was because the rainfall from the NWP-WRF model was lower than the measured rainfall. In Summary, the simulated flow rates for the rivers using data rom NWP-WRF were higher than the observations flow at Ribb River and lower than at Gummara River. The maximum forecasted flow at Ribb was $141 \mathrm{~cm}$ but the maximum 


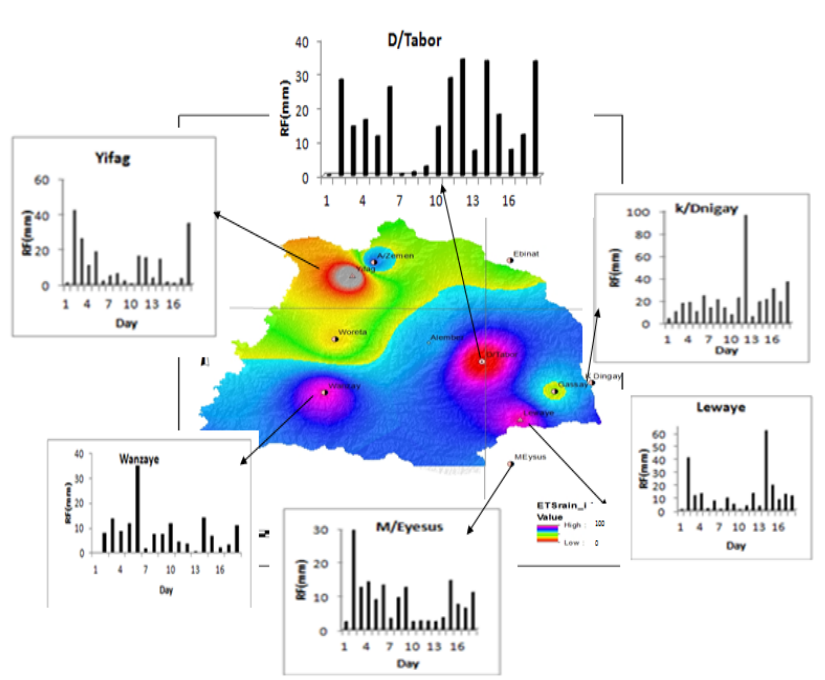

Figure 4: Forecasted rainfall for selected stations of Eastern Tana Sub Basin.

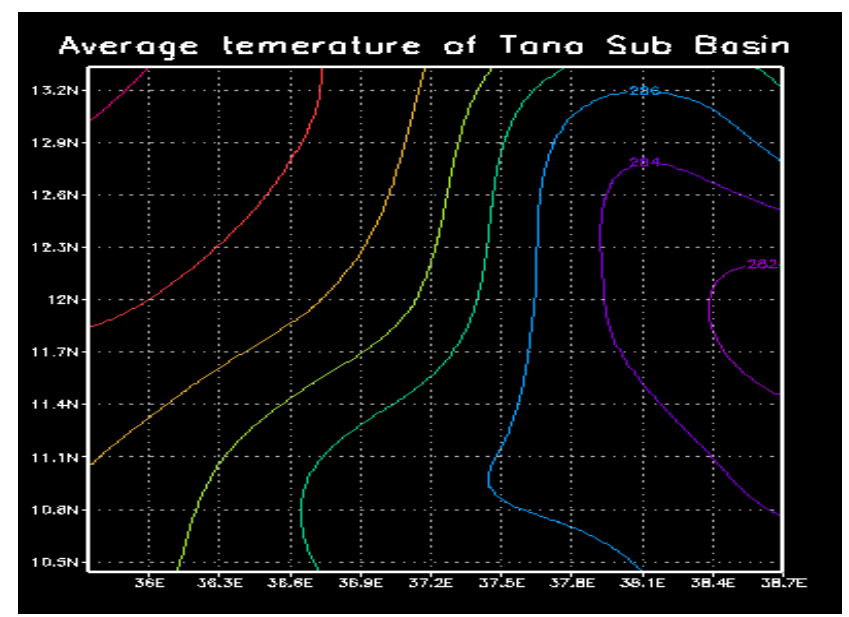

Figure 5: Forecasted Temperature for Eastern Tana Sub basin.

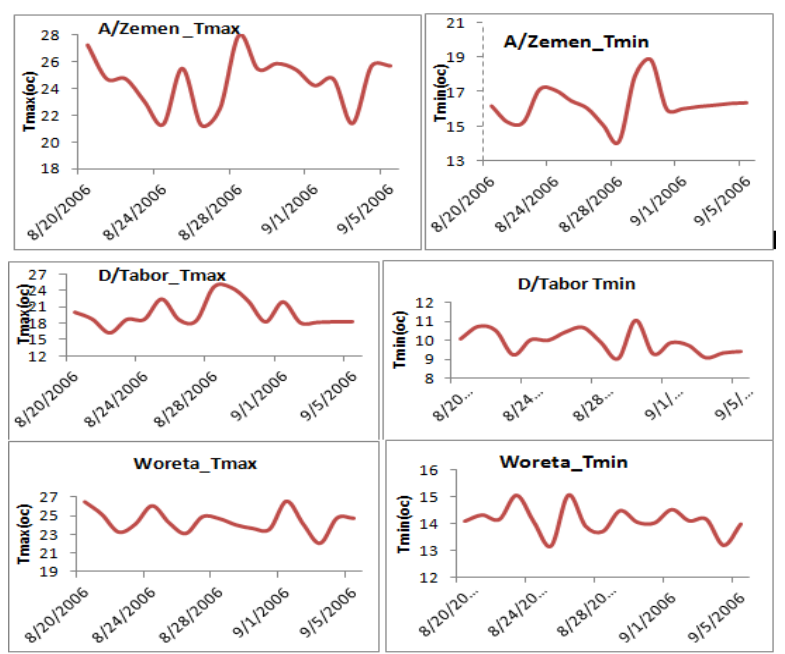

Figure 6: Forecasted Temperature for the selected stations Eastern Tana Sub Basin.

\begin{tabular}{|c|c|c|c|c|}
\hline \multirow{2}{*}{ Watershed } & \multicolumn{2}{|c|}{ Calibration } & \multicolumn{2}{c|}{ Validation } \\
\cline { 2 - 5 } & NSE & $\mathbf{R}^{\mathbf{2}}$ & NSE & $\mathbf{R}^{\mathbf{2}}$ \\
\hline Gummara & 0.75 & 0.77 & 0.73 & 0.74 \\
\hline Ribb & 0.72 & 0.73 & 0.67 & 0.76 \\
\hline
\end{tabular}

Table 1: SWAT Model Calibration.
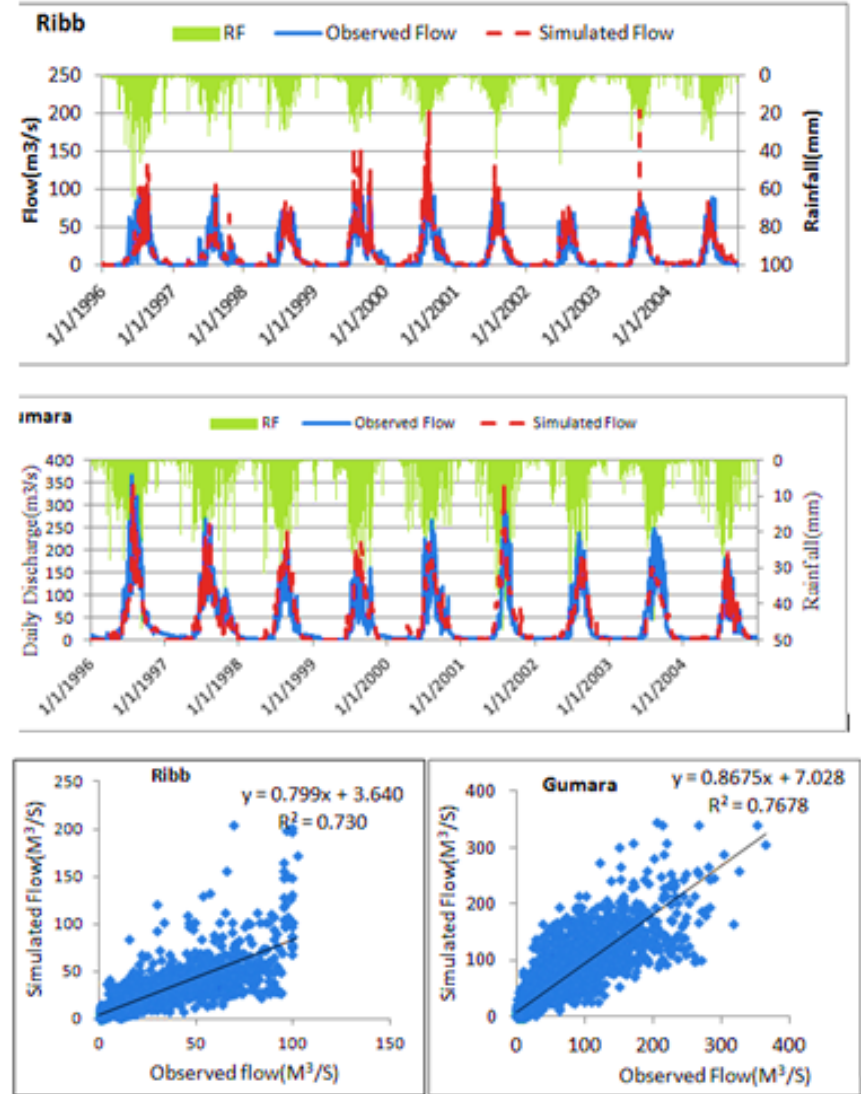

Figure 7: Calibration-Comparisons of simulated and observed flow.

observed flow was $93 \mathrm{~cm}$. Similarly, for Gummara, the maximum forecasted and observed flow was $185 \mathrm{~cm}$ but the maximum observed flow was $206 \mathrm{~cm}$ (Figure 9).

\section{Flood modeling}

Both upstream and downstream boundary conditions have given for the diffusive channel solver. The upstream boundary is the forecasted flow rate at gauging site of Ribb and Gummara rivers; and the downstream boundary condition is the Lake Tana water level. The advantage of the diffusive channel solver over Kinematic solver is that the tributaries have handled automatically by LISFLOOD-FP. To simulate a dynamic flood wave both upstream and downstream time varying boundary condition (QVAR and HVAR) have used.

The forecasted flood extent for the design period 20 August 200610 September 2006 has computed by integrating the hydrology model (SWAT) and a hydrodynamics model (LISFLOOD). The output from SWAT that is a hydrograph used as upper boundary for LISFLOOD model and the Lake level interims of elevation used as lower boundary. Therefore, the LISFLOOD computes the flood extent on accounts of the boundary conditions, the rivers width, and river cross-section and 

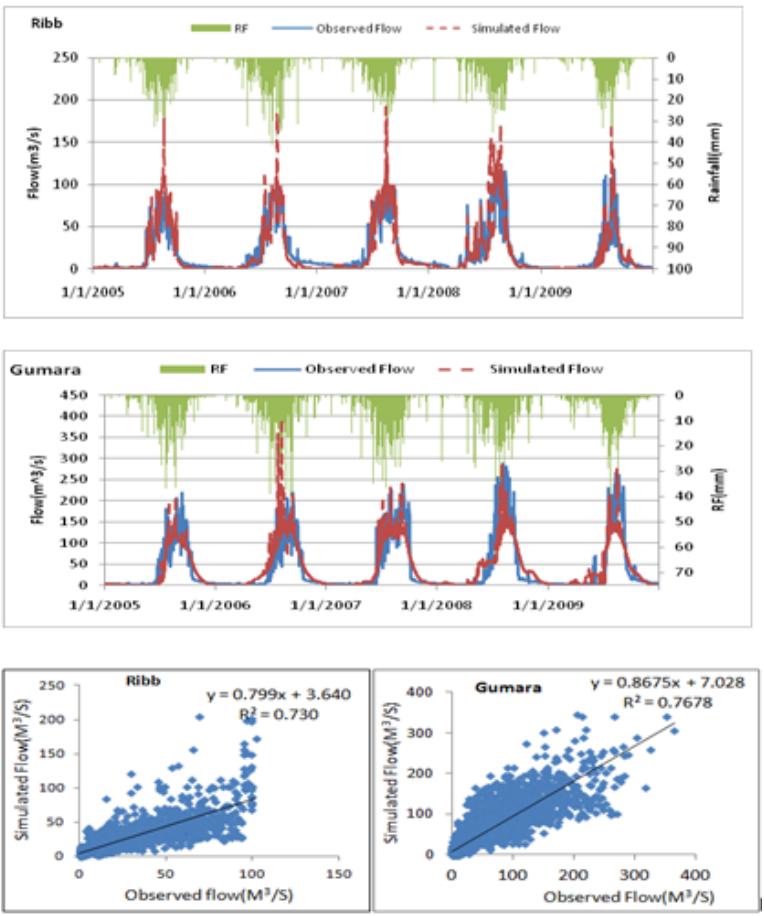

Figure 8: Validation-Comparisons of simulated and observed flow.

Manning's friction coefficient.

The flood extent obtained from LISFLOOD-FP has processed on GIS environment. The extent of flood for the forecasted period is 329 $\mathrm{Km}^{2}$. The flood depth ranges from $0.01 \mathrm{~m}$ to $3.5 \mathrm{~m}$ and the maximum depth is at the rivers. The flood velocity for the forecasted period ranges from 0 to $2.375 \mathrm{~m} / \mathrm{s}$. The model has not accounted the rainfall over the flood plain and the small rivers those are not tributary of the main rivers (Ribb and Gummara) (Figure 10). This might be under estimate the flood extent.

\section{Flood model verification}

The goodness of fit between the created flood map from flood model and the flood map extracted from the satellite images has assessed by the measure of Relative Error (RE) and F-statistics (F). As shown the Figure 11 indicates that the inundation area of the extracted flood images from the satellite is $259.7 \mathrm{Km}^{2}$ and predicted flood inundation area is $256.9 \mathrm{Km}^{2}$. The area of overlapping portion of the two flood inundations is $236.55 \mathrm{Km}^{2}$ with $\mathrm{RE}$ of 0.01 and F-statistics of $84.47 \%$. This shows that the compared areas of the flood inundation are similar to each other but they are not geospatially similar. As can be seen in Figure 11 the satellite image shows more flooded area in the side of Ribb River but the forecasted flood area is more in the Gummara riverside. This seems rescannable because the satellite image also accounts the logged water over the area due to rainfall and other tributaries. Near to the Ribb, river and center of the flood plain there are tributaries, which are causing flood.

The goodness of fit between the created flood map from flood model and the flood map extracted from the satellite images in Table 2 shows that the model has well fitted.

$$
\text { Where, } R E=\frac{\left|\mathrm{A}_{\mathrm{o}}-\mathrm{A}_{\mathrm{p}}\right|}{\mathrm{A}_{\mathrm{p}}}
$$

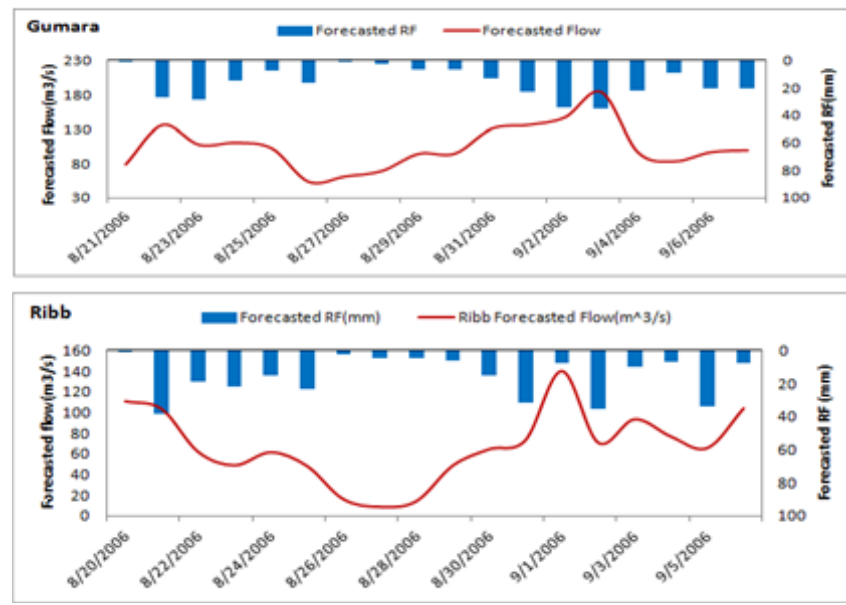

Figure 9: Forecasted flow over Gumara and Ribb Gauges and rainfall over the study area.

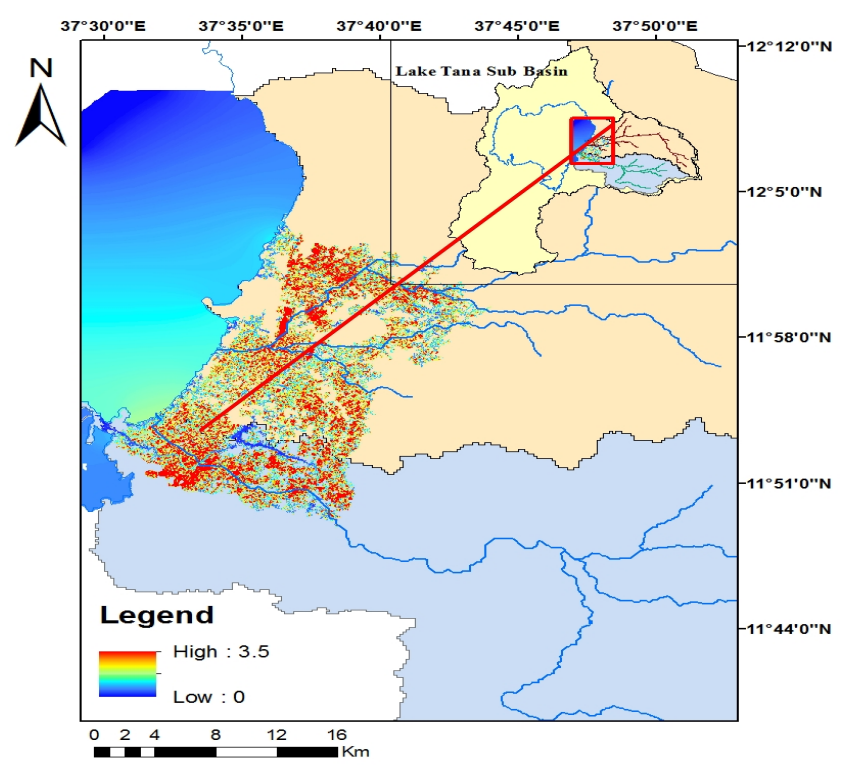

Figure 10: Forecasted flood extent for 20 Aug, 2006-10 Sep, 2006.

$$
F=\left(\frac{A_{o p}}{A_{o}+A_{p}-A_{o p}}\right) \times 100
$$

$\mathrm{A}_{\mathrm{o}}$ indicates the inundation area of the extracted flood images from the satellite

$A_{p}$ refers to the predicted flood inundation area

$\mathrm{A}_{\mathrm{op}}$ represents the intersection of $\mathrm{A}_{\mathrm{o}}$ and $\mathrm{A}_{\mathrm{p}}$.

\section{Conclusion and Recommendations}

Flooding is the main challenge natural hazard in Eastern Tana 


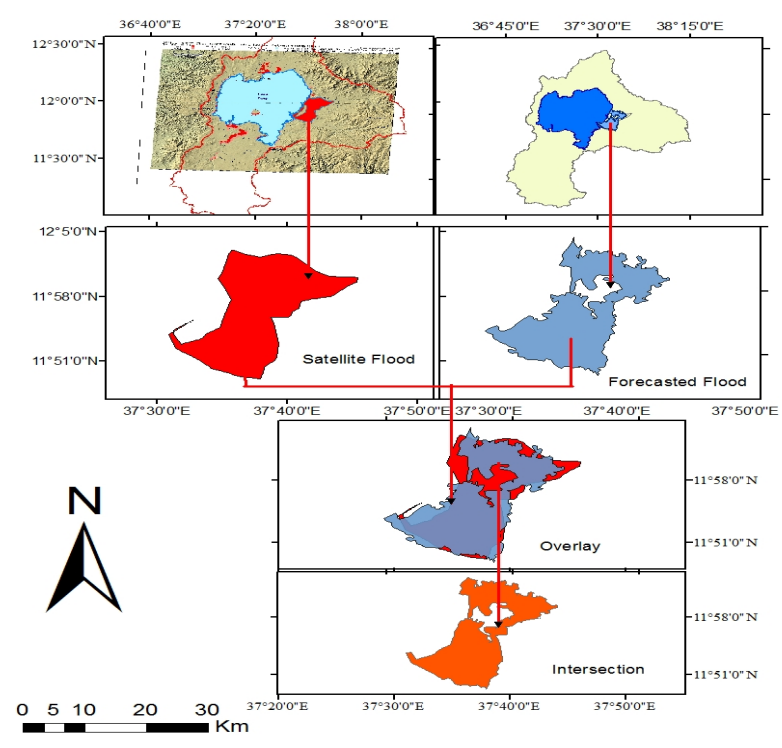

Figure 11: The forecasted and Satellite flood inundation map.

\begin{tabular}{|c|c|c|}
\hline Year & RE & F \\
\hline 2006 & 0.011 & 84.47 \\
\hline
\end{tabular}

Table 2: Measure of goodness of fit of the satellite image and forecasted flood extent.

sub Basin that affects human life and property badly. Thousands of people are displacing each year and the people in the area are always a misery due to flood. The Ethiopian government has taken an operation measure to control the impact of flood but the measure has abused by the farmers that they love the flood to get fertile soil.

The extreme weather over the study area is controlled by the movement of the Inter-Tropical Convergence Zone (ITCZ) position and orientation, monsoon trough, Low level jet (Somali Jet), Southern hemisphere high pressures, Southerly (cross equatorial) moisture flows, Strengthening frequency of Tropical Easterly Jet (TEJ), ENSO events and seasonal rainfall features Wet/dry summer (La Nina/El Nino).

Flooding has estimated by integrating three models (WRF-SWATLISFLOOD) and the approach that gave a good result. Even though the main source of flood was included in the flood model domain during flood modeling, few sources have left (the rainfall and the tributaries over the floodplain). This will a little bit underestimated the estimated flood. This work is the first work in Ethiopia and the method can extend for other regions with similar/different climates.

The ongoing rapid land use change and expansion of agricultural area in this study area will have negative effects on the runoff properties. To attenuate the occurrence of flood on Fogera flood plain, a better land use management system is required, which can impede the unregulated conversion from one land use to another land use. To avoid future flood disasters, flood early warning and forecasting system, flood management and flood mitigation plans are need to be able to react quickly to areas affected by flooding. Flood monitoring system is required to assess, on a continuous basis, the areas affected by floods and to have emergency measures plan to reduce the damage of exceptional floods. Also, need to aware the community/ farmers about the effect of flood strongly to solve problems related to dyke breaking.

Further investigations should consider on the possibility of flood forecasting and modeling with including other events in the area. Future works are needed on establishing early warning system by considering the outputs of this study.

\section{Acknowledgements}

I would like to thank the Blue Nile Water Institute for funding this research and providing necessary facilities. First, I would like to express my sincere gratitude to my advisors Dr. Solomon Demissie and Dr. Seifu Admassu for the continuous support of my study and research, for their patience, motivation, enthusiasm, and immense knowledge. Their guidance helped me in all the time of research and writing of this thesis. I could not have imagined having a better advisor for my research. My sincere thanks also go to Dr. Essayas Kaba, Mr. Fasikaw Atanaw and Mr. Mamaru Moges for their guidance and help on land use classification, guiding on writ up of my thesis under difficult condition and crowded time.

\section{References}

1. Parry M (2007) Climate Change 2007: impacts, adaptation and vulnerability. Contribution of Working Group II to the fourth assessment report of the Intergovernmental Panel on Climate Change, Cambridge University Press.

2. Barrientos HG, Swain A (2014) Linking flood management to integrated water resource management in guatemala: A critical review. International Journal of Water Governance 4: 53-74.

3. Berz G (2000) Flood disasters: lessons from the past-worries for the future Proc Inst Civ Eng Water Marit Energy 142: 3-8.

4. Bryan E, Deressa T, Gbetibouo G, Ringler C (2009) Adaptation to climate change in Ethiopia and South Africa: Options and constraints. Environ. Sci. Policy 12: 413-426.

5. Deressa TT, Hassan RM, Ringler C, Alemu T, Yesuf M (2009) Determinants of farmers' choice of adaptation methods to climate change in the Nile Basin of Ethiopia. Global environmental change 19: 248-255.

6. Kebede S, Travi Y, Alemayehu T, Marc V (2006) Water balance of Lake Tana and its sensitivity to fluctuations in rainfall, Blue Nile basin, Ethiopia. Journal of hydrology 16: 233-247.

7. Williams JR, Arnold JG, Kiniry JR, Gassman PW, Green CH (2008) History of model development at Temple, Texas. Hydrological sciences journal 53: 948960.

8. Arnold J, Srinivasan RS, Muttiah RS, Williams JR (1998) Large area hydrologic modeling and assessment part I: Model development. Journal of the American Water Resources Association (JAWRA) 34: 73-89.

9. Demirel MC, Venancio A, Kahya E (2009) Flow forecast by SWAT model and ANN in Pracana basin, Portugal. Advances in Engineering Software 40: 467473.

10. Wangpimool W, Pongput K, Supriyasilp T, Kamol PN, Sakolnakhon S, et al. (2013) Hydrological evaluation with swat model and numerical weather prediction for flash flood warning system in Thailand. Journal of Earth Science and Engineering 3: 349.

11. Rivera S, Hernandez A, Ramsey RD, Suarez G (2007) Predicting flood hazard areas: a swat and HEC-RAS simulations conducted in Aguan river basin of Honduras, Central America. Paper presented at ASPRS 2007 Annual Conference.

12. Jung CG, Joh HK, Yu YS, Park JY, Kim SJ (2012) Study on damage reduction by flood inundation and the sediments by SWAT and HEC-RAS modeling of flow dynamics with watershed hydrology-for 27 july 2011 heavy storm event at GonjiamCheon watershed. Journal of the Korean Society of Agricultural Engineers 54: 87-94

13. Neitsch SL, Arnold JG, Kiniry JR, Williams JR (2011) Soil and water assessment tool theoretical documentation version 2009. Texas Water Resources Institute Technical Report No. 406, Texas Water Resources Institute.

14. Setegn SG, Srinivasan R, Dargahi B (2008) Hydrological modelling in the Lake Tana Basin, Ethiopia using SWAT model. The Open Hydrology Journal 2: 4962.

15. Yang J, Peter R, Abbaspour KC, Xia J, Yang H (2008) Comparing uncertainty analysis techniques for a SWAT application to the Chaohe Basin in China Journal of Hydrology 358: 1-23

16. Roo APJD, Wesseling C, Deursen WV (2000) Physically based river basin modelling within a GIS: the LISFLOOD model. Hydrological Processes 14 1981-1992. 
Citation: Desalegn A, Demissie S, Admassu S (2016) Extreme Weather and Flood Forecasting and Modelling for Eastern Tana Sub Basin, Upper Blue Nile Basin, Ethiopia. Hydrol Current Res 7: 257. doi: 10.4172/2157-7587.1000257

Page 8 of 8

17. Roo AD, Gouweleeuw B, Pozo JT, Sattler K (2003) Development of a European flood forecasting system. International Journal of River Basin Management 1: 49-59.

18. Roo APJD (1999) LISFLOOD: a rainfall-runoff model for large river basins to assess the influence of land use changes on flood risk in RIBAMOD: river basin modelling, management and flood mitigation, concerted action by European Communities, pp: 349-358

19. Trigg MA, Wilson MD, Bates PD, Horritt MS, Alsdorf DE, et al. (2009) Amazon flood wave hydraulics. Journal of Hydrology 374: 92-105.

20. White KL, Chaubey I (2005) Sensitivity analysis, calibration, and validations for a multisite and multivariable SWAT model. Journal of the American Water Resources Association (JAWRA) 41: 1077-1089.

21. Santhi C, Arnold JG, Williams JR, Dugas WA, Srinivasan R, et al. (2001) Validation of the SWAT model on a large river basin with point and nonpoint sources. Journal of the American Water Resources Association (JAWRA) 37: 1169-1188. 